\title{
Mengelola Keuangan Keluarga yang Baik di Desa Gumuk Rejo
}

\author{
Rusmiati ${ }^{1}$, \& Sigit Priyono ${ }^{2}$ \\ STKIP Nurul Huda Sukaraja OKU Timur, \\ E-mail: ${ }^{1}$ rusmiati@stkipnurulhuda.ac.id, ${ }^{2}$ sigitpriyono@stkipnurulhuda.ac.id
}

INFO ARTIKEL

ABSTRAK

How to cite (APA):

Rusmiati, R., \& Priyono, S. (2019). Mengelola Keuangan Keluarga yang Baik di Desa Gumuk Rejo. Jurnal Indonesia Mengabdi, 1(2), 54-56. Retrieved from

http://journal.stkipnurulhuda.ac.id/i ndex.php/JIMi/article/view/597

ISSN 2685-3035

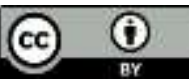

This work is licensed under a Creative Commons Attribution 4.0 International License

\begin{abstract}
Abstrak
Masalah utama sebuah keluarga yang selalu ada biasanya seputar keuangan. Bisa karena kekurangan uang, kelebihan uang, atau karena bingung bagaimana mengatur uang bagi orang yang penghasilannya paspasan, sedangkan kebutuhan selalu melebihi pemasukan. Namun muara dari itu semua, kata kuncinya adalah bagaimana mengatur keuangan keluarga atau pribadi dengan cerdas, cermat dan sebaik-baiknya. Mengelola keuangan merupakan kunci utama dalam menggapai kesuksesan keuangan. Apalagi dengan semakin meningkatnya biaya hidup di zaman sekarang ini menuntut kita untuk lebih cerdas dalam mengatur keuangan agar tidak terjerat utang. Oleh karena itu, kita harus mengelola keuangan keluarga supaya tidak besar pengeluaran daripada pendapatan. Kata kunci: Mengelola Keuangan, Keluarga
\end{abstract}

\section{Abstract}

The main problem of a family that is always there is usually about finance. Could be due to lack of money, excess money, or because of confusion about how to manage money for people whose income is mediocre, while the needs always exceed income. But the mouth of it all, the key word is how to manage family or personal finances with smart, careful and the best. Managing finance is the main key in achieving financial success. Especially with the increasing cost of living in today's era requires us to be smarter in managing finances so as not to get into debt. Therefore, we must manage family finances so that expenses are not greater than income. Keyword: Managing Finace, Family

\section{PENDAHULUAN}

Masalah utama sebuah keluarga yang selalu ada biasanya seputar keuangan. Bisa karena kekurangan uang, kelebihan uang, atau karena bingung bagaimana mengatur uang bagi orang yang penghasilannya pas-pasan, sedangkan kebutuhan selalu melebihi pemasukan. Namun muara dari itu semua, kata kuncinya adalah bagaimana mengatur keuangan keluarga atau pribadi dengan cerdas, cermat dan sebaik-baiknya.

Penghasilan sebesar apapun tidak akan pernah cukup untuk memenuhi semua kebutuhan jika kita tidak tahu cara mengatur keuangan. Orang kaya sekalipun pasti akan mengalami masalah keuangan jika tidak tahu cara mengatur keuangan dengan baik.

Mengelola keuangan merupakan kunci utama dalam menggapai kesuksesan keuangan. Apalagi dengan semakin meningkatnya biaya hidup di zaman sekarang ini menuntut kita untuk lebih cerdas dalam mengatur keuangan agar tidak terjerat utang.

Mengatur keuangan bukan saja memperhitungkan setiap pemasukan dan pengeluaran, tapi juga belajar bagaimana cara agar kedua hal tersebut dapat berjalan secara seimbang, tidak besar pasak daripada tiang sehingga menimbulkan defisit keuangan. Oleh karena itu, kita perlu mengetahui secara rinci apa saja pengeluaran jangka pendek dan jangka panjang, serta melakukan upaya penghematan.

Mengelola keuangan keluarga merupakan keterampilan dasar yang perlu dimiliki setiap rumah tangga, terutama rumah tangga miskin. Umumnya masalah keuangan mereka adalah lebih besarnya pengeluaran dibanding pendapatan, serta tidak teraturnya jumlah dan waktu menerima pendapatan, pengetahuan dan keterampilan mengelola keuangan sangat terbatas. Tanpa pengelolaan keuangan yang baik maka pengeluaran akan lebih besar daripada pendapatan sehingga untuk mengatasi masalah tersebut mereka berhutang yang berakibat pada kesulitan untuk membayar 
utang beserta bunganya dan uang yang ada semakin tidak cukup.

\section{METODE PELAKSANAAN}

Metode pelaksanaan dalam kegiatan pengabdian ini adalah pelatihan. Dimana pelatihan diterapkan untuk memberikan penjelasan materi kepada ibu rumah tangga dari keluarga penerima manfaat program keluarga harapan desa Gumuk Rejo. Metode yang digunakan dalam pelaksanaan kegiatan ini adalah ceramah, diskusi, dan simulasi menghitung pendapatan dan pengeluaran serta memutarkan film tentang pengelolaan keuangan.

\section{HASIL DAN PEMBAHASAN Hasil}

Pendampingan kegiatan ini memberikan materi pelatihan tentang mengidentifikasi sumbersumber pendapatan dan jenis-jenis pengeluaran keluarga, menghitung jumlah pendapatan dan pengeluaran keluarga setiap bulannya, memahami perbedaan kebutuhan dan keinginan, menyusun prioritas pengeluaran untuk menyeimbangkan pengeluaran dengan pendapatan, menyusun anggaran keuangan, memahami pentingnya menjalankan anggaran yang telah dibuat, mengetahui pilihan cara untuk mengendalikan pengeluaran, membuat catatan kas harian.

Pelaksanaan kegiatan sesuai dengan tahapan adalah sebagai berikut:

\section{Tabel 1. Pelaksanaan Kegiatan}

\begin{tabular}{llc}
\hline No & Materi & Tutor \\
\hline 1 & 1. Memahami tujuan pelatihan & Rusmiati, Sigit Priyono
\end{tabular}

2. Merasa nyaman dan siap menerima materi pelatihan

3. Mengidentifikasi sumber-sumber pendapatan dan jenisjenis pengeluaran keluarga

4. Menghitung jumlah pendapatan dan pengeluaran keluarga setiap bulannya

2 1. Memahami perbedaan kebutuhan dan keinginan Rusmiati, Sigit Priyono

2. Menyusun prioritas pengeluaran untuk menyeimbangkan pengeluaran dengan pendapatan

3. Menyusun anggaran keuangan

3 1. Memahami pentingnya menjalankan anggaran yang telah Rusmiati, Sigit Priyono dibuat

2. Mengetahui pilihan cara untuk mengendalikan pengeluaran

3. Membuat catatan kas harian

$4 \quad$ Simulasi latihan soal menghitung tentang pendapatan dan Rusmiati, Sigit Priyono pengeluaran dalam keluarga

\section{Pembahasan}

Hasil dari kegiatan pengabdian kepada masyarakat ini mendapatkan respon yang positif dari pemerintah desa serta dari ibu-ibu rumah tangga dari keluarga penerima manfaat program keluarga harapan karena memang materi ini sangat dibutuhkan mereka dalam mengatur keuangan keluarga. Mereka sangat bersemangat untuk mengikuti kegiatan ini. Pelaksanaan pelatihan ini dengan cara ceramah, diskusi, dan simulasi menghitung pendapatan dan pengeluaran serta memutarkan film tentang pengelolaan keuangan. Setelah kegiatan ini dilaksanakan diharapkan keterampilan ibu rumah tangga dalam mengelola keuangan keluarga lebih baik lagi sehingga tidak besar pengeluaran daripada pendapatan sehingga mereka terhindar dari jeratan utang.

\section{SIMPULAN}

Dari kegiatan pengabdian kepada masyarakat ini dapat disimpulkan bahwa setelah mengikuti pelatihan pengelolaan keuangan ibu rumah tangga di desa Gumuk Rejo kecamatan Buay Madang Timur dapat lebih baik lagi dalam mengatur atau mengelola keuangan rumah tangga sehingga tidak besar pengeluaran daripada pendapatan sehingga mereka terhindar dari jeratan utang.

\section{UCAPAN TERIMAKASIH}

Ucapan terima kasih ditujukan kepada Ketua STKIP Nurul Huda Sukaraja, Ketua LPPM STKIP Nurul Huda, yang berkenan untuk memfasilitasi kegiatan pengabdian kepada masyarakat ini. 
Mengelola Keuangan Keluarga yang Baik di Desa Gumuk Rejo

Jurnal Indonesia Mengabdi, 1(2), 2019

Serta kepada TIM pengabdian yang telah beruapaya sekuat tenaga demi kesuksesan kegiatan ini.

\section{DAFTAR PUSTAKA}

Bank Indonesia. (2013). Pengelolaan Keuangan Modul Pelatihan. Jakarta: Bank Indonesia

Lppm. (2018). Panduan Pelaksanaan Penelitian \& Pengabdian Kepada Masyarakat Edisi Revisi Juli 2018. LPPM STKIP Nurul Huda.

Manullang, M. (2003). Dasar-dasar Manajemen. Jakarta: Ghalia Indonesia

OJK. (2014). Perencanaan Keuangan Keluarga. Jakarta: Otoritas Jasa Keuangan 